\title{
Thermal Conductivity of Compressed Earth Bricks Strengthening by Shea Butter Wastes with Cement
}

\author{
Herve Goure Doubi ${ }^{*}$, Alfred Niamien Kouamé2, Léon Koffi Konan², Monique Tognonvi, \\ Samuel Oyetola ${ }^{2}$ \\ ${ }^{1}$ Unité de Formation et de Recherche des Sciences biologiques, Université Péléforo Gon Coulibaly de Korhogo, Korhogo, \\ Côte d'Ivoire \\ ${ }^{2}$ Laboratoire de Chimie des Matériaux Inorganiques (LCMI), Université Félix Houphouët-Boigny de Cocody-Abidjan, Abidjan, \\ Côte d'Ivoire \\ Email: *goure_herve2610@yahoo.fr
}

How to cite this paper: Doubi, H.G., Kouamé, A.N., Konan, L.K., Tognonvi, M. and Oyetola, S. (2017) Thermal Conductivity of Compressed Earth Bricks Strengthening by Shea Butter Wastes with Cement. Materials Sciences and Applications, 8, 848-858.

https://doi.org/10.4236/msa.2017.812062

Received: September 15, 2017

Accepted: November 4, 2017

Published: November 7, 2017

Copyright $\odot 2017$ by authors and Scientific Research Publishing Inc. This work is licensed under the Creative Commons Attribution International License (CC BY 4.0).

http://creativecommons.org/licenses/by/4.0/

\section{(c) (i) Open Access}

\begin{abstract}
Currently, in a context of sustainable development, the economic and environmental challenges incite, to valorize local materials such as clays and agro-industrial waste. It is in this approach that a new category of compressed earth bricks (BTC) stabilized with shea meal (TK) and cement was proposed. The purpose of this paper is to investigate the effect of shea meal rate on the thermal conductivity properties of cement stabilized earth bricks. A lateritic clay (Lat) mainly composed of kaolinite (38.44\%), quartz (24.94\%), goethite (12.28\%), hematite (4.44\%) and illite (19.9\%) was used to make bricks. Different mix designs made up of lateritic clay and $5 \%$ cement were studied. The shea meal is added as a partial lateritic clay replacement in different proportions. The thermal conductivity was determined by hot disk method and correlated to both porosity and density of elaborated materials. The results obtained show that the thermal conductivity and density of bricks decrease respectively from $0.72 \mathrm{~W} \cdot \mathrm{m}^{-1} \cdot \mathrm{K}^{-1}$ to $0.52 \mathrm{~W} \cdot \mathrm{m}^{-1} \cdot \mathrm{K}^{-1}$ and from $2.77 \mathrm{~g} \cdot \mathrm{cm}^{-3}$ to 2.52 $\mathrm{g} \cdot \mathrm{cm}^{-3}$. The presence of shea meal within the material generates pore formation, which may partly explain the improvement of the thermal insulation properties. A positive correlation was noted between density and thermal conductivity of these materials.
\end{abstract}

\section{Keywords}

Lateritic Clay, Shea Meal, Compressed Earth Brick (CEB), Thermal Conductivity and Eco-Materials 


\section{Introduction}

All human activities (industry, transport, deforestation, agriculture, construction, etc.) generate a high concentration of greenhouse gases in the atmosphere, leading to the global warming that the world has been facing in recent years. This has direct consequence of the natural disasters such as drought, melting glaciers, floods, hurricanes, etc.

The construction sector plays an important role as the construction process requires significant energy demand and causes environmental side effects, namely: greenhouse gas emissions, high water consumption, as well as the production of solid and liquid wastes [1] [2] [3]. Given the current global concerns for sustainable development resulting from environmental problems such as climate change and resource depletion, coupled with the rapid pace of technological advancement in the building sector, interest in alternative building materials such as earth has developed.

The earth, because of its availability and ease of implementation, is indeed an ideal building material. Its extraction, processing, production and transport require very little energy. Moreover, the earth is $100 \%$ recyclable and provides an interior comfort since it is a good thermal, humidity and acoustic regulator. However, the technology of compressed earth bricks (CEB) or stabilized earth bricks (SEB) still uses a significant amount of cement [4].

Earthen construction has been used for several thousand years in various parts of the world [5]. But such a building suffers from certain deficiencies, such as mechanical strength, water resistance and durability [6] [7]. To overcome these problems, plant debris, fly ash or small amounts of cement or lime are commonly added [8] [9].

Furthermore, the production of shea butter generates a significant amount of waste called shea meal. The shea (its scientific name Vitellaria paradoxa) is a tree that grows wild in the savanna regions in the North of Côte d'Ivoire. The shea meal which is constituted of $50 \%-75 \%$ of shea butter seeds, cannot be used for livestock feed because of its high lignite content [10] and is a source of environmental pollution. As well, it has been shown that the sticky black residue, left after extraction of the shea butter, can be used to fill the cracks in the walls and as a waterproofing material [10]. Shea meal could therefore be used in addition to lime or cement in the production of compressed earth brick in order to improve both the mechanical, chemical and durability properties of the bricks. In the region of Korhogo, it is very hot, the temperatures often reach $36^{\circ} \mathrm{C}$. This encourages researchers to propose alternative solutions based on sustainable materials "eco-materials", environmentally friendly and have good thermal insulation properties.

The thermal conductivity of clay-based materials has been studied extensively, mainly in the case of materials consolidated with thermal treatments for applications in building. The thermal conductivity depends strongly on the nature of raw materials, temperature of thermal treatment during which transformations 
in the solid phases occur and obviously the final pore volume fraction [11] [12]. The values for clay-based material are often below $1 \mathrm{~W} \cdot \mathrm{m}^{-1} \cdot \mathrm{K}^{-1}[13]$.

The purpose of this work is to study the impact of shea meal rate on the thermal conductivity of cement-stabilized earth bricks.

\section{Materials and Methods}

\subsection{Materials}

Lateritic clay (Lat) used is from the Hambol region (Côte d'Ivoire), precisely in town of Katiola. This clay is extracted from quarries located around the geographical coordinates: $08^{\circ} 09.030^{\prime} \mathrm{North}, 005^{\circ} 05.850^{\prime}$ West and altitude $996 \mathrm{~m}$ extends over about $10 \mathrm{Km}^{2}$ at a depth of $1 \mathrm{~m} 50$ (Figure 1).

Cement (C) called "LE CLASSIC" was used for paste. The shea meal (TK) collected from the preparation site of shea butter located in the city of Korhogo (North of Côte d'Ivoire) was used as additives and/or clay replacement for the elaboration of compressed earth bricks.

\subsection{Methods}

The Chemical composition of the clay used in this study was determined by means of Inductively Coupled Plasma Atomic Emission Spectrometry (ICP-AES) method. Prior to analysis, the clay sample dried at $110^{\circ} \mathrm{C}$ for 24 hours was dissolved using an ANTON Paar type microwave under acidic (fluorhydric and nitric acids) and high pressure conditions. The dissolution was carried out in a 50 min cycle: a $10 \mathrm{~min}$ temperature rise followed by a $40 \mathrm{~min}$ step at maximum temperature $\left(260^{\circ} \mathrm{C}\right)$ and cooling to $35^{\circ} \mathrm{C}$.

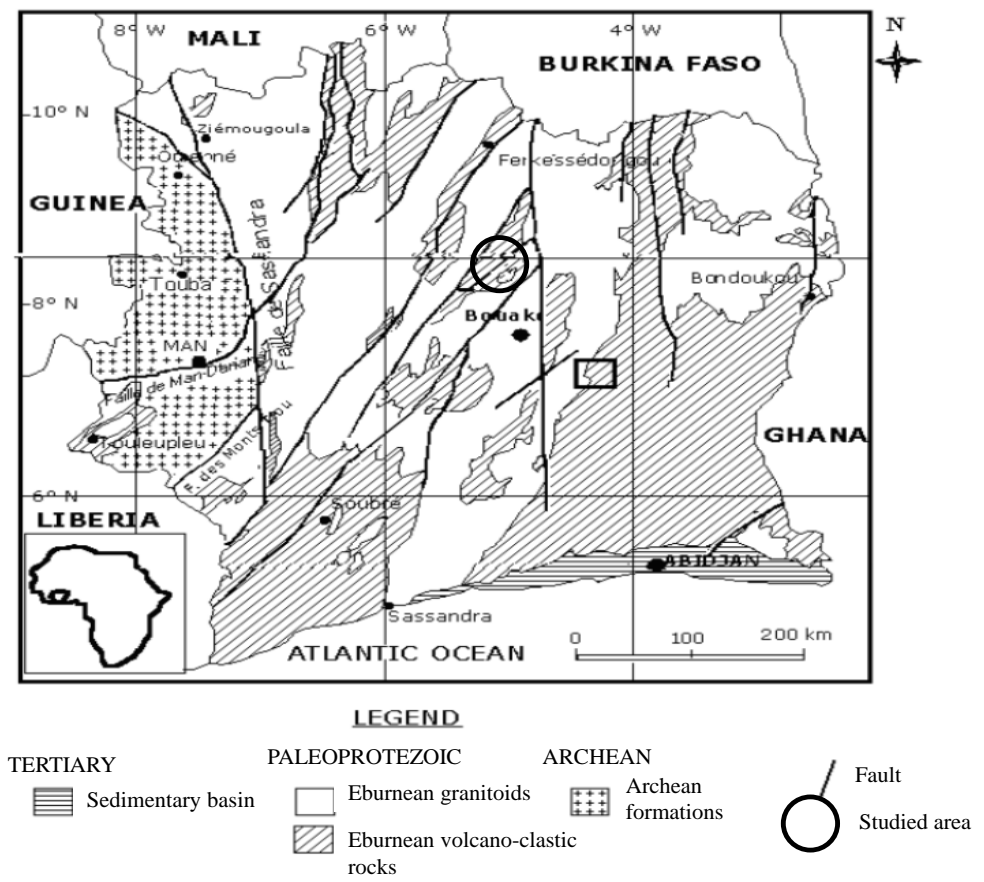

Figure 1. Extraction site of the lateritic clay of Katiola town [14]. 
The crystalline mineralogical phases were determined using a Bruker multifunctional D8 ADVANCE model diffractometer. Measurements were conducted on powdered samples using continuous scanning mode in $2 \theta$ range of $2^{\circ}-70^{\circ}$ with a step size of $0.01^{\circ}(2 \theta)$ and a counting time of $0.25 \mathrm{~s}$.

The thermal behavior of the clay sample was followed using a SETSYS Evolution equipment from SETARAM for temperatures range from $30^{\circ} \mathrm{C}$ to $1200^{\circ} \mathrm{C}$ under dried-air atmosphere with a rise rate of $5^{\circ} \mathrm{C} / \mathrm{min}$. Alumina powder, previously calcined at $1500^{\circ} \mathrm{C}$ for 1 hour was used as reference material. The specific area of the clay was determined by Brunauer Emmett and Teller (BET) method using Micromeritics TriStar II [15]. Measurements were performed after 16 hours degassing-step at $200^{\circ} \mathrm{C}$ on the crushed and sieved samples at $100 \mu \mathrm{m}$.

The porosity was obtained using the ratio of pore volume to the total volume of material. The porosity rate was determined by the expression provided in Equation (1).

$$
\text { Porosity rate }=\left[1-\left(\rho_{s} / \rho_{p}\right)\right] \times 100
$$

where $\rho_{s}$ is the density of the material calculated using both dimensions and mass of the material.

$\rho_{p}$, is the density of the solid measured using the helium pycometer.

The thermal conductivity of CEB samples was determined by hot disk method. This technique gives directly access to the thermal conductivity of the material. The basic principle of measurement consists in inserting a probe between two cylindrical blocks of the material. The probe acts both as a source of heat (Joule's effect) and a sensor of the rise in temperature. The measurement consists in imposing a power to the sample from an instant $(t=0)$ and in following the rise of the probe temperature over time. The analysis of the increase in temperature as a function of time gives access to the thermal conductivity of the material.

\subsection{Elaboration of the Compressed Earth Brick Samples (CEB)}

Several samples of CEB with different compositions containing lateritic clay, cement and shea meals were manufactured. All components were dry-blended in a Contrelab brand kneader at a speed of $70 \mathrm{rpm}$ for about $10 \mathrm{~min}$. The mixture is moistened with $20 \%$ of water and then kneaded again for $20 \mathrm{~min}$. The compaction was carried out using a hydraulic press under a pressure of $40 \mathrm{MPa}$. The compositions of earth bricks obtained from the different mixtures are given as a percentage of dry mass of each component (Table 1). All samples were oven-dried at $40^{\circ} \mathrm{C}$ for 7 days prior to analyses.

\section{Results and Discussion}

\subsection{Characterization of the Raw Lateritic Clay (Lat)}

Chemical compositions as well as physical parameters of the lateritic clay (Lat) are recorded in Table 2. Analysis of the results obtained shows that the Lat used 
Table 1. Different compressed earth brick (CEB) formulation and their porosity rate.

\begin{tabular}{ccccc}
\hline Samples & Clay (\%) & Shea meal (\%) & Cement (\%) & Porosity rate (\%) \\
\hline $\mathrm{Lat}_{100}$ & 100 & - & - & 35.3 \\
$\mathrm{Lat}_{93} \mathrm{TK}_{2} \mathrm{C}_{5}$ & 93 & 2 & 5 & 28 \\
$\mathrm{Lat}_{91} \mathrm{TK}_{4} \mathrm{C}_{5}$ & 91 & 4 & 5 & 33.6 \\
$\mathrm{Lat}_{89} \mathrm{TK}_{6} \mathrm{C}_{5}$ & 89 & 6 & 5 & 33.3 \\
$\mathrm{Lat}_{87} \mathrm{TK}_{8} \mathrm{C}_{5}$ & 87 & 8 & 5 & 33.8 \\
$\mathrm{Lat}_{85} \mathrm{TK}_{10} \mathrm{C}_{5}$ & 85 & 10 & 5 & 38.4 \\
\hline
\end{tabular}

Table 2. Chemical and mineralogical compositions and physical characteristics of raw lateritic clay (Lat).

\begin{tabular}{|c|c|c|c|c|c|c|c|}
\hline \multirow{2}{*}{$\begin{array}{l}\text { Chemical } \\
\text { composition (wt\%) }\end{array}$} & $\mathrm{SiO}_{2}$ & $\mathrm{Al}_{2} \mathrm{O}_{3}$ & $\mathrm{Fe}_{2} \mathrm{O}_{3}$ & $\mathrm{~K}_{2} \mathrm{O}$ & $\mathrm{Na}_{2} \mathrm{O}$ & $\mathrm{TiO}_{2}$ & $\mathrm{SiO}_{2} / \mathrm{Al}_{2} \mathrm{O}_{3}$ \\
\hline & 57.51 & 23.12 & 15.67 & 2.35 & 0.73 & 0.83 & 2.49 \\
\hline $\begin{array}{c}\text { Mineralogical } \\
\text { composition (wt\%) }\end{array}$ & \multicolumn{7}{|c|}{$\begin{array}{c}\text { Kaolinite }=38.44 ; \text { Illite }=19.9 ; \text { Goethite }=12.28 ; \\
\text { Hematite }=4.44 ; \text { Quartz }=24.94\end{array}$} \\
\hline Specific area $\left(\mathrm{m}^{2} \cdot \mathrm{g}^{-1}\right)$ & \multicolumn{7}{|c|}{25.62} \\
\hline $\begin{array}{l}\text { Density } \\
\left(\mathrm{g} \cdot \mathrm{cm}^{-3}\right)\end{array}$ & \multicolumn{7}{|c|}{2.8} \\
\hline Plasticity index & \multicolumn{7}{|c|}{17} \\
\hline $\begin{array}{l}\text { Methylene blue value } \\
\quad(\mathrm{g} / 100 \mathrm{~g} \text { soil })\end{array}$ & \multicolumn{7}{|c|}{0.5} \\
\hline
\end{tabular}

is mainly composed of aluminum, silicon and iron oxides. However, it also contains some minor elements such as potassium, sodium and titanium oxides. The $\mathrm{K}_{2} \mathrm{O}$ content of $2.35 \mathrm{wt} \%$ suggests the presence of mica. The $\mathrm{SiO}_{2} / \mathrm{Al}_{2} \mathrm{O}_{3}$ weight ratio is of 2.48 instead of 1.18 for pure kaolinite [16]. This high value suggests the presence of free-form of silica and clays minerals type 2:1 [17]. Based on Lacroix's classification of lateritic soils [18], the clay containing $15.67 \%$ by mass of iron oxide used belongs to the family of lateritic clays. The specific area and density of this clay are respectively $25.62 \mathrm{~m}^{2} \cdot \mathrm{g}^{-1}$ and $2.8 \mathrm{~g} \cdot \mathrm{cm}^{-3}$. The density of this clay is consistent with that generally observed in lateritic soils $\left(2.5\right.$ to $\left.3.7 \mathrm{~g} \cdot \mathrm{cm}^{-3}\right)$. Maignian [19] who works on laterites showed that the density of the lateritic clays increases with the iron oxide content, decreases with the alumina content and depends on its chemical composition. The plasticity index (PI) and Methylene Blue Value (MBV) are respectively 17 and 0.5 . The values of plasticity index $(12<\mathrm{PI}<25$ and MBV $<1.5)$ show that the clay used in our study is a sandy loam soil and belongs to class A2 according to the Earthworks Guides classification. Therefore, this material is suitable for use in the manufacture of compressed earth brick (CEB).

Figure 2 shows X-ray diffraction of lateritic clay, it shows the presence of iron compounds, silicate phases and clay minerals of the 2:1 phyllosilicates family. It consists mainly of kaolinite $\left(\mathrm{Si}_{2} \mathrm{Al}_{2} \mathrm{O}_{5}(\mathrm{OH})_{4}\right)$, quartz $\left(\mathrm{SiO}_{2}\right)$, hematite $\left(\alpha-\mathrm{Fe}_{2} \mathrm{O}_{3}\right)$, goethite $(\alpha-\mathrm{FeOOH})$ and illite $\left(\mathrm{KAl}_{3} \mathrm{Si}_{3} \mathrm{O}_{10}(\mathrm{OH})_{2}\right)$. 


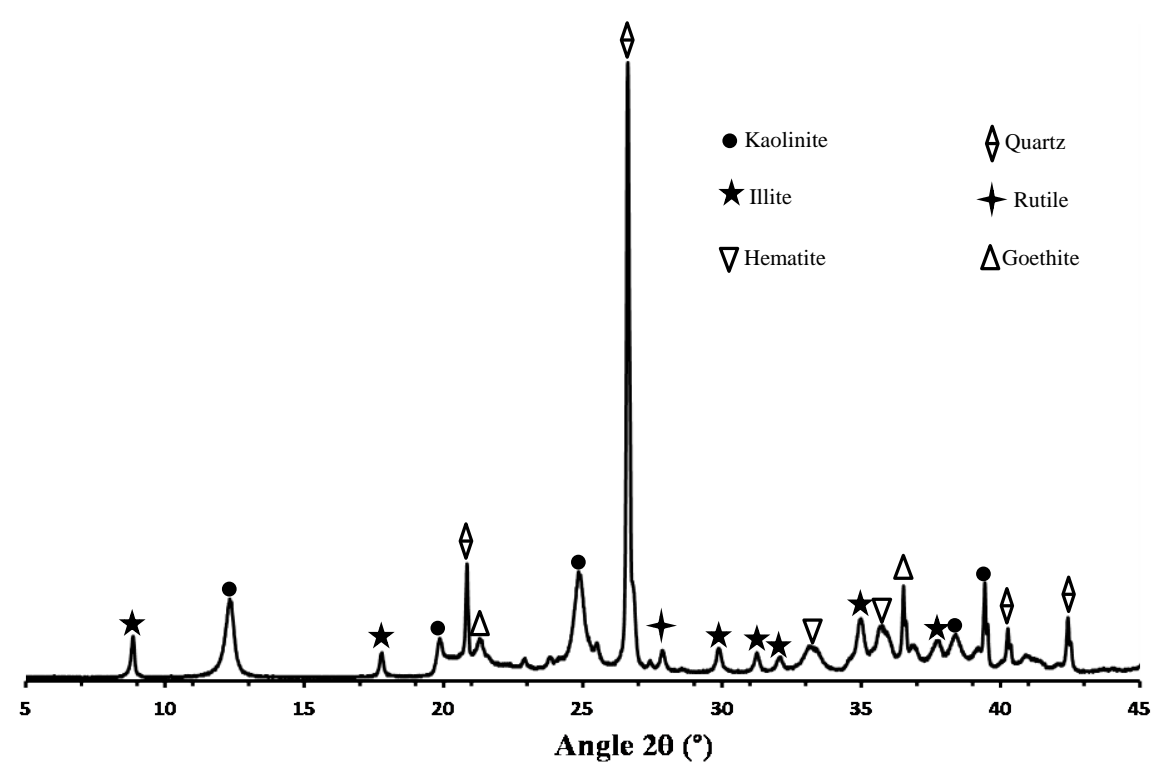

Figure 2. XRD diagram of the raw lateritic clay.

The thermal analysis (DTA-TGA) results of the raw lateritic clay are presented on Figure 3. The following transformations can be observed:

$\checkmark \mathrm{A}$ first mass loss (0.5\%) observed between $30^{\circ} \mathrm{C}$ and $100^{\circ} \mathrm{C}$ and associated with an endothermic peak is due to the departure of free water (physisorbed water).

$\checkmark$ A second mass loss (1.25\%) observed between $200^{\circ} \mathrm{C}$ and $350^{\circ} \mathrm{C}$ is the consequence of the dehydroxylation of goethite into hematite [20] (Equation (1):

$$
2 \mathrm{FeOOH} \rightarrow \mathrm{Fe}_{2} \mathrm{O}_{3}+\mathrm{H}_{2} \mathrm{O}
$$

A third mass loss $(6 \%)$ is observed between $400^{\circ} \mathrm{C}$ and $600^{\circ} \mathrm{C}$. This mass loss could due to the superposition of two phenomena, namely dehydroxlation of kaolinite Equation (2) and illite in lateritic clay [21]:

$$
\mathrm{Si}_{2} \mathrm{Al}_{2} \mathrm{O}_{5}(\mathrm{OH})_{4} \rightarrow \mathrm{Si}_{2} \mathrm{Al}_{2} \mathrm{O}_{7}+2 \mathrm{H}_{2} \mathrm{O}
$$

At $572^{\circ} \mathrm{C}$, an endothermic phenomenon which corresponds to the transition of quartz $(\alpha \rightarrow \beta)$ is observed.

$\checkmark$ At around $954^{\circ} \mathrm{C}$, an exothermic peak was observed. It is due to the structural reorganization of metakaolinite in a spinel phase [21]. The reaction is as follows:

$$
2\left[\mathrm{Si}_{2} \mathrm{Al}_{2} \mathrm{O}_{7}\right] \rightarrow \mathrm{Si}_{3} \mathrm{Al}_{4} \mathrm{O}_{12}+\mathrm{SiO}_{2}
$$

Calculations based on the results of the chemical analysis, differential thermal and thermogravimetry analysis and the ideal chemical composition of the phases detected by X-ray diffraction, allow to obtain the mineralogical composition of the lateritic clay (Table 2). These calculations show that kaolinite (38.44\%), illite (19.9\%), quartz (24.94\%) and goethite (12.28\%) are the main phases of the raw material (Lat). The hematite is present but in very low quantity. The phases relating to titanium are found in trace form. 


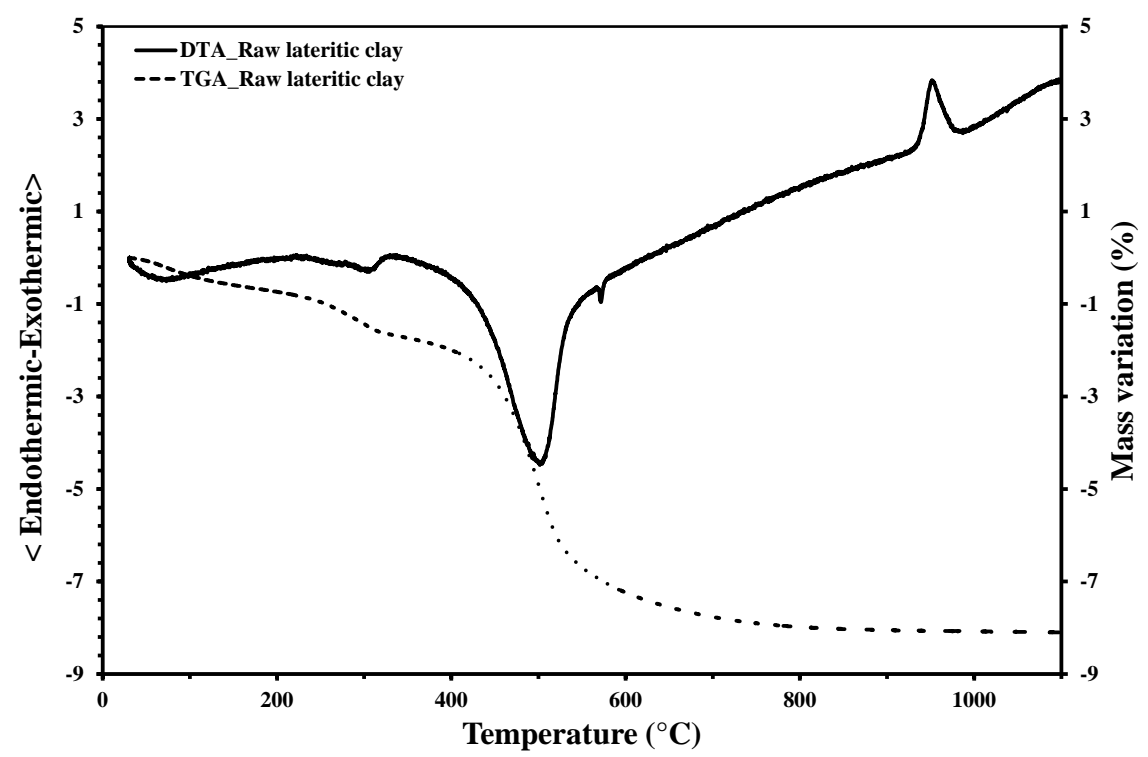

Figure 3. Differential thermal and thermogravimetric analyses of raw lateritic clay.

\subsection{Physical Properties of Compressed Earth Bricks (CEB) Reinforced With Shea Meals with Cement}

The influence of shea meal rate on both the density and the thermal conductivity of compressed earth bricks was studied and the correlation between the two studied parameters was also discussed. Figure 4 shows effects of the shea meal content on CEB density. The results show a decrease in density from $2.77 \mathrm{~g} \cdot \mathrm{cm}^{-3}$ to $2.52 \mathrm{~g} \cdot \mathrm{cm}^{-3}$ (about $9 \%$ of decrease) and a slight increase in porosity in the elaborated samples from $35 \%$ to $38 \%$ (Table 1). These observations are in accordance with results obtained by Ashour et al. and Bachir et al. To explain this decrease, these authors have issued different assumptions. According to Bachir et al., the decrease in density with increasing the amount of fiber or organic matter would be linked to a decrease in homogeneity, an improvement in the bonds and an increase in the porosity rate. According to Ashour et al. the replacement of cement or gypsum (dense materials) with wheat or barley fibers (less dense materials) results in an increase in the total volume of the mixture. This increase in the volume of compacted mixture results in a decrease in the weights and densities of the samples [22] [23].

Figure 5 shows the evolution of the thermal conductivity and the porosity rate of the CEB produced as a function of the content of the shea meal. When the shea meal content is changed from $0 \%$ to $2 \%$, the thermal conductivity increases from $0.72 \mathrm{~W} \cdot \mathrm{m}^{-1} \cdot \mathrm{K}^{-1}$ to $0.86 \mathrm{~W} \cdot \mathrm{m}^{-1} \cdot \mathrm{K}^{-1}$. This increase is partly due to the reduction of the porous network in the material from $35 \%$ to about $28 \%$ and to the large amount of cement-based phases $\left(\mathrm{CSH}, \mathrm{C}_{3} \mathrm{AH}_{3} \ldots.\right)$. This results from the hydration of the cement, which contributes to increase the rigidity of the material structure. Therefore, heat transfer is improved in the material. When the shea meal content is higher than that of the cement, the thermal conductivity of the material decreases and the porosity rate increases from $28 \%$ for the material 


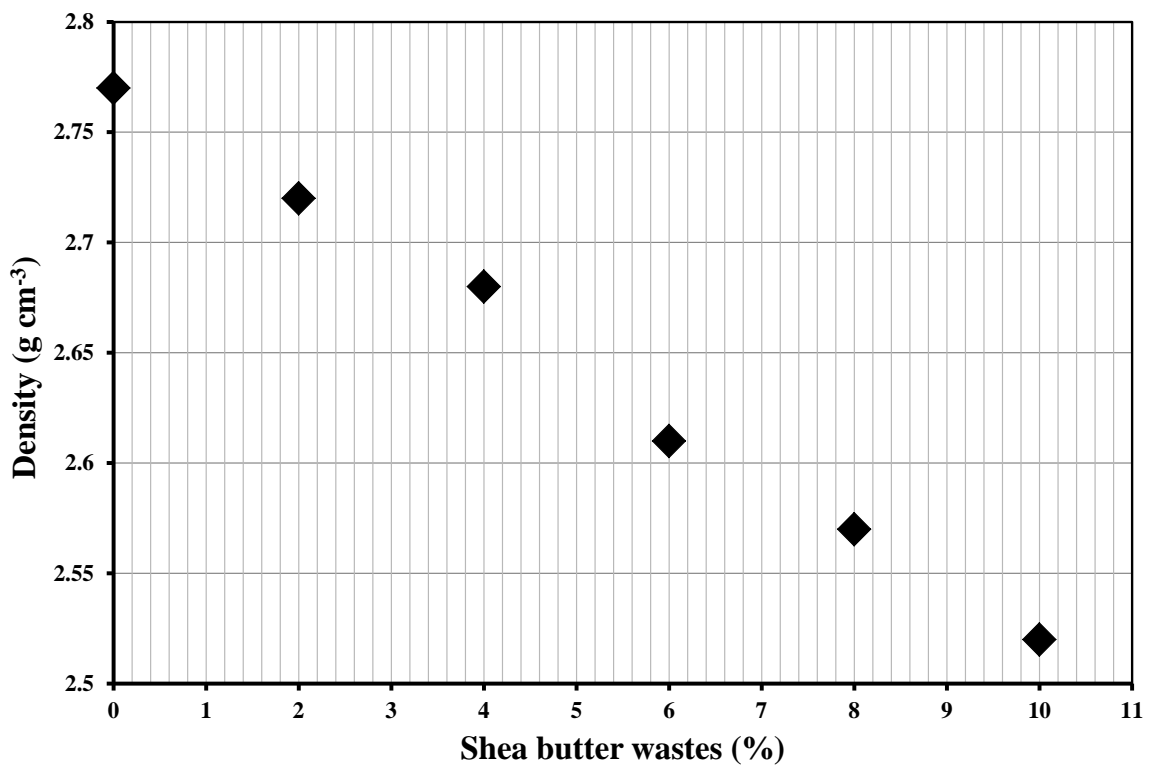

Figure 4. Effect of the shea meal content on the density of CEB stabilized with $5 \%$ of cement.

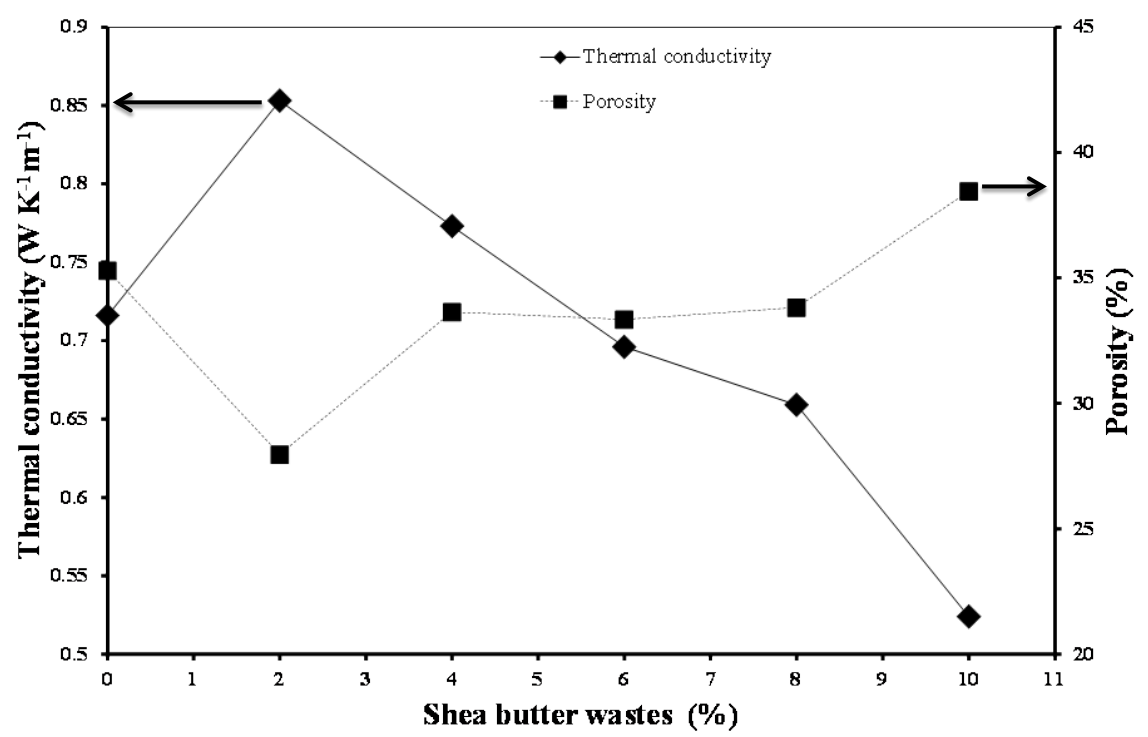

Figure 5. Effect of the shea meal content on the thermal conductivity of CEB stabilized with $5 \%$ of cement.

containing $2 \%$ shea meal to about $33 \%$ for the samples containing $6 \%$ and $8 \%$ shea meal.

However, this porosity rate remains lower than that of the material without shea meal. The decrease of thermal conductivity value observed could be explained by the known low thermal conductivity of organic matter. On the other hand, when the shea meal content reaches $10 \%$, the thermal conductivity reaches a value of $0.52 \mathrm{~W} \cdot \mathrm{m}^{-1} \cdot \mathrm{K}^{-1}$, i.e. a reduction of about $27 \%$ relative to the material without shea meal and the porosity rate increases from $33 \%$ to $38 \%$. According to the literature, the increase in organic matter rate within the material results in 
a decrease of the thermal conductivity. Two main arguments were used to explain this thermal conductivity decrease. Firstly, the presence of fiber or organic materials within the material generates the creation of pores, which consequently results in a decrease of its thermal conductivity. Secondly, the organic materials are characterized by a low thermal conductivity with respect to the argillaceous matrix [24] [25]. In order to better understand the thermal behavior of compressed earth bricks reinforced with shea meal and cement, a relation between the thermal conductivity and the density of these materials has been established. And a positive correlation between both parameters is observed (Figure 6). The low value of the correlation coefficient $\left(r^{2}=0.619\right)$ shows a lower correlation between density and thermal conductivity. This is coherent because a material is less dense has more void between these particles, resulting in a decrease in the thermal conductivity. It can be noted that for the low values thermal conductivity correspond to the lowest of the density. Except for a shea meal content of $0 \%$, in this case the density is highest but the thermal conductivity is lower than that of the sample with $2 \%$ shea butter waste. This would explain the low value of the correlation coefficient $\left(\mathrm{r}^{2}=0.619\right)$ between thermal conductivity and density.

\section{Conclusions}

The main objective of this work was to study the influence of shea meal on the thermal properties of stabilized earth bricks (CEB) with cement. In order to do so, a lateritic clay composed mainly of kaolinite, quartz, hematite, goethite and illite, shea meals recovered from the shea butter manufacturing in the Korhogo region and cement were used. Different formulations from lateritic clay and 5\% cement were studied. This study shows that the presence of shea meal causes the

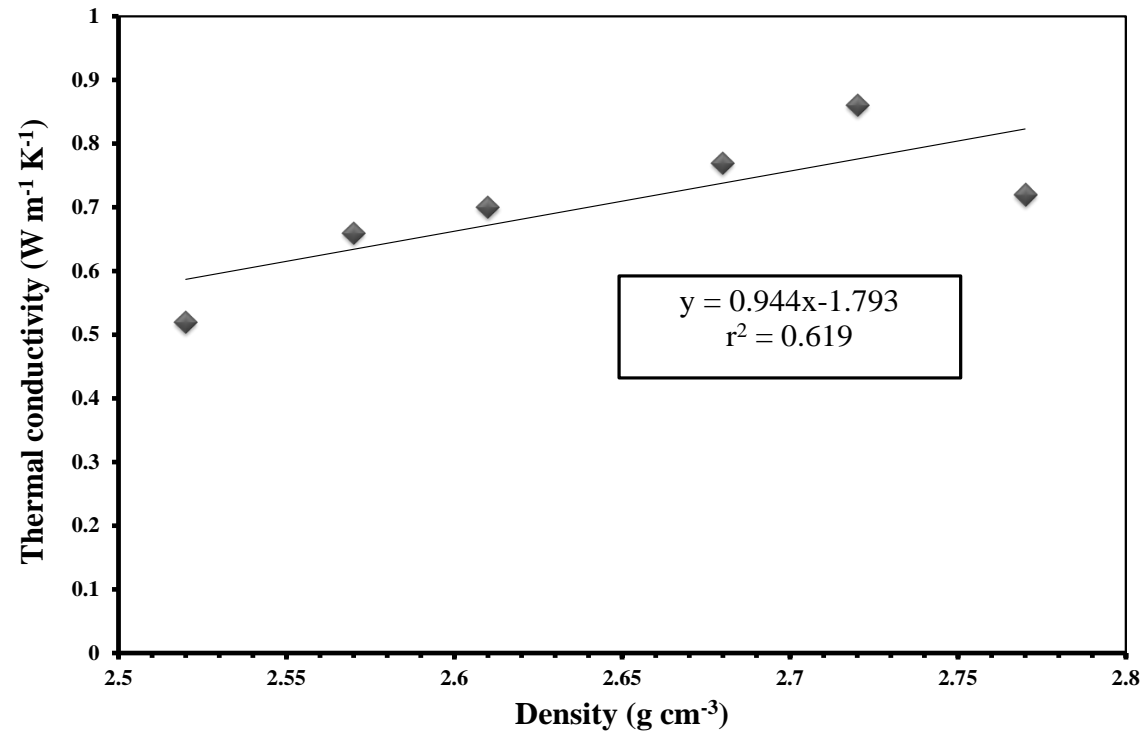

Figure 6. Correlation between density and thermal conductivity of CEB stabilized with $5 \%$ of cement and shea meal ( $0 \%$ to $10 \%)$. 
creation of pores in the material. An increase in the amount of shea meal $(0 \%$ to $10 \%)$ results in a decrease in the density of the produced material. This has an impact on the thermal conductivity of these bricks. The thermal conductivity varies from $0.72 \mathrm{~W} \cdot \mathrm{m}^{-1} \cdot \mathrm{K}^{-1}$ for the sample containing $0 \%$ shea meal to 0.52 $\mathrm{W} \cdot \mathrm{m}^{-1} \cdot \mathrm{K}^{-1}$ for that containing $10 \%$. The shea meal improves the thermal insulation properties of elaborated bricks. A good correlation between the thermal conductivity and the density of these bricks could be noted.

This exploratory work has made it possible to show the possibility to use the shea meal in building materials. However, the understanding of the interactions of organic matter and the mineral phases deserves deepening. Consideration should be given to also the development of these materials with other types of clay minerals.

\section{References}

[1] Ashour, T., Korjenic, A., Korjenic, S. and Wu, W. (2015) Thermal Conductivity of Unfired Earth Bricks Reinforced by Agricultural Wastes with Cement and Gypsum. Energy and Buildings, 104, 139-146. https://doi.org/10.1016/j.enbuild.2015.07.016

[2] Pacheco-Torgal, F. and Jalali, S. (2012) Earth Construction: Lessons from the Past for Future Eco-Efficient Construction. Construction and Building Materials, 29, 512-519. https://doi.org/10.1016/j.conbuildmat.2011.10.054

[3] Doukas, H., Patlitziana, K.D., Kagiannas, A.G. and Psarras, J. (2006) Renewable Energy Sources and Rationale Use of Energy Development in the Countries of GCC: Myth or Reality? Renewable Energy, 31, 755-770. https://doi.org/10.1016/j.renene.2005.05.010

[4] Guillaud, H., Joffroy, T. and Odul, P. (1995) CRATerre-EAG, Blocs de terre comprimée, volume 2. Manuel de conception et de construction. [Compressed Earth Blocks, Volume 2. Design and Construction Manual.] GATE-GTZ \& Building Advisory Service and Information Network.

[5] Montgomery, D.E. (2002) Dynamically-Compacted Cement Stabilised Soil Blocks for Low-Cost Walling. Ph.D. Thesis, University of Warwick, Warwich.

[6] Riza, F.V., Abdul Rahman, I. and Zaidi, A.M.A. (2011) Preliminary Study of Compressed Stabilized Earth Brick (CSEB). Australian Journal of Basic and Applied Sciences, 5, 6-12.

[7] Alam, I., Naseer, A. and Shah, A.A. (2015) Economical Stabilization of Clay for Earth Buildings Construction in Rainy and Flood Prone Areas. Construction and Building Materials, 77, 154-159.

[8] Arabi, M. and Wild, S. (1986) Microstructural Development in Cured Soil-Lime Composites. Journal of Materials Science, 21, 497-503. https://doi.org/10.1007/BF01145514

[9] Attoh-Okine, B. (1990) Stabilizing Effect of Locally Produced Lime on Selected Lateritic Soils. Construction and Building Materials, 4, 86-91.

[10] Van der Vossen, H.A.M. and Kamilo, M. (2007) Ressources végétale de l'Afrique tropical 14. Oléagineux. [Tradcution de: Plant Ressources of Tropical Africa 14. Vegetable Oils.] Fondation PROTA, Wagenngen, Pays-bas/Backhyus Publishers, Leiden, Pays-Bas/CTA, Wageningen, Pays-Bas, GS (Editeurs), 261.

[11] Gualtieri, M.L., Gualtieri, A.F., Gagliardi, S., Ruffini, P., Ferrari, R. and Hanuskova, 
M. (2010) Thermal Conductivity of Fired Clays: Effects of Mineralogical and Physical Properties of the Raw Materials. Applied Clay Science, 49, 269-275.

[12] García-Ten, J., Orts, M.J., Saburit, A. and Silva, G. (2010) Thermal Conductivity of Traditional Ceramics: Part II: Influence of Mineralogical Composition. Ceramics International, 36, 2017-2024.

[13] Kornmann, M. (2007) Clay Bricks and Roof Tiles: Manufacturing and Properties. Société de l'industrie Minérale, Paris.

[14] Tagini, B. (1971) Esquisse Structural de la Côte d'Ivoire. Essai de géotectonique régionale. [Structural Sketch of the Côte d'Ivoire. Regional Geotectonic Test.] Thèse de Doctorat Université de Lausanne.

[15] Brunauer, S., Emmett, P.H. and Teller, E. (1938) Adsorption of Gases in Multimolecular Layers. Journal of the American Chemistry Society, 60, 309. https://doi.org/10.1021/ja01269a023

[16] Lecomte-Nana, G., Bonnet, J.P. and Soro, N. (2013) Influence of Iron onto the Structural Reorganization Process during the Sintering of Kaolins. Journal of European Ceramic Society, 33, 661-668.

[17] Jouenne, C.A. (1990) Traité de céramiques et matériaux minéraux. [Treaty of Ceramics and Mineral Materials.] Edition Septima, Paris.

[18] Lacroix, A. (1913) Les Latérites de Guinée et les produits d'altération qui leur sont assocés. [The Laterites of Guinea and the Products of Alteration Associated with Them.] In: Nouvelles Archives du Muséum D' Histoire Naturelle, 255-356.

[19] Maignien, R. (1958) Le cuirassement des sols en Guinée, Afrique Occidentale. [The Cuirassement of Soil in Guinea, West Africa.] Thèse Sciences Université de Lorraine Strasbourg, 239.

[20] Farmer, V.C. (1974) The Layer Silicates. In the Infrared Spectra of Minerals. Mineralogical Society, London. https://doi.org/10.1180/mono-4

[21] Belloto, M., Gualtieri, A., Artioli, G. and Clark, S.M. (1995) Kinetic Study of the Kaolinite-Mullite Reaction Sequence. Part I: Kaolinite Dehydroxylation. Physics and Chemistry of Minerals, 22, 207-214.

[22] Ashour, T., Korjenic, A. and Korjenic, S. (2015) Equilibrium Moisture Content of Earth Bricks Biocomposites Stabilized with Cement and Gypsum. Cement \& Concrete Composites, 59, 18-25.

[23] Taallah, B. and Guettala, A. (2016) The Mechanical and Physical Properties of Compressed Earth Block Stabilized with Lime and Filled with Untreated and Alkali-Treated Date Palm Fibers. Construction and Building Materials, 104, 52-62.

[24] Al-Oqla, F.M. and Sapuan, S.M. (2014) Natural Fiber Reinforced Polymer Composites in Industrial Applications: Feasibility of Date Palm Fibers for Sustainable Automotive Industry. Journal of Cleaner Production, 66, 347-354.

[25] Benmansour, N., Agoudjil, B., Gherabli, A., Karechea, A. and Boudenne, A. (2014) Thermal and Mechanical Performance of Natural Motar Reinforced with Date Palm Fibers for Use as Insulating Materials in Building. Energy Build, 81, 98-104. 